\title{
Kan sykdomsforebyggende tiltak for leger påvirke risikofaktorer for suicid?
}

\author{
Av Karin Isaksson Rø
}

\section{SAMMENDRAG}

Høye suicidrater blant leger og internasjonale rapporter om utbrenthet, depressive plager og alkoholbruk førte til en bekymring for norske legers helse, med mulige konsekvenser for legene selv og for pasientbehandlingen. Studier av legers helse ble initiert og sykdomsforebyggende tiltak ble opprettet med mål om å forebygge psykiske plager, der suicid var en ytterst mulig konsekvens. Da prevalensen av suicid er lav, er det viktig å studere tiltakenes påvirkning på risikofaktorer for suicid. Fem ulike sykdomsforebyggende tiltak for leger presenteres: Legeforskningsinstituttet (LEFO), Støttekollegaordningen, Ressurssenteret Villa Sana, Lege-for-lege-ordningen og et tilbud for leger med rusproblemer. Studier av tiltakene indikerer at de har betydning for risikofaktorer for suicid, som depressive symptomer, utbrenthet og hjelpsøking. Dette kan ha betydning for gruppen av leger som direkte oppsøker tiltakene, men også for en holdningsendring $\mathrm{i}$ profesjonen mot å i større grad kunne søke hjelp ved behov. Behov for en kombinasjon av organisatoriske og forebyggende tiltak diskuteres.

\section{ABSTRACT}

High suicide rates among doctors and international reports of burnout, depressive symptoms and alcohol use led to a concern for Norwegian doctors' health, with possible consequences for the doctors themselves and for patient treatment. Studies of doctors' health were initiated and preventive measures were established with the aim of preventing mental illness, where suicide was an ultimate consequence. As the prevalence of suicide is low, it is important to study the impact of the measures on risk factors for suicide. Five different preventive interventions for doctors are presented: Institute for Studies of the Medical Profession-LEFO, a Peer-Support Scheme, the Resource Centre Villa Sana, the Doctor-forDoctors scheme and a Scheme for doctors with substance abuse problems. Studies of the measures indicate that they can impact risk factors for suicide, such as depressive symptoms, burnout and help-seeking. This can be important for the group of doctors who avail themselves of the interventions, but also for a change of attitude in the profession generally towards more easily seeking help if needed. The need for a combination of organizational and individually oriented preventive measures is discussed.

LEGERS PSYKISKE HELSE har betydning både for legene selv og for pasientbehandlingen (Baathe et al., 2019; Casalino \& Crosson, 2015; Panagioti et al., 2018; Wallace et al., 2009). Høyere suicidrater blant leger enn i befolkningen har vært en viktig motivasjon for studier av legers psykiske helse og opprettelse av sykdomsforebyggende tiltak for leger.

Internasjonale rapporter om høye suicidrater blant leger, høy andel leger med arbeidsrelatert stress og utbrenthet, bekymringsfull forekomst av depressivitet og av alkoholbruk samt lav grad av hjelpsøking førte på 1980-tallet til en bekymring for norske legers psykiske helse (Rutle et al., 1988), og bekymring for suicid som den alvorligste konsekvensen av dette.

For å få vite hvordan situasjonen var blant norske leger ble det tatt initiativ til studier av legers helse, arbeidsforhold og dødsårsaker (Aasland, 1995), og Legeforeningen opprettet flere sykdomsforebyggende tiltak for leger.

Også i Norge fant man høyere suicidrater blant leger enn i flere andre yrkesgrupper (Aasland et al., 2001). Fra 


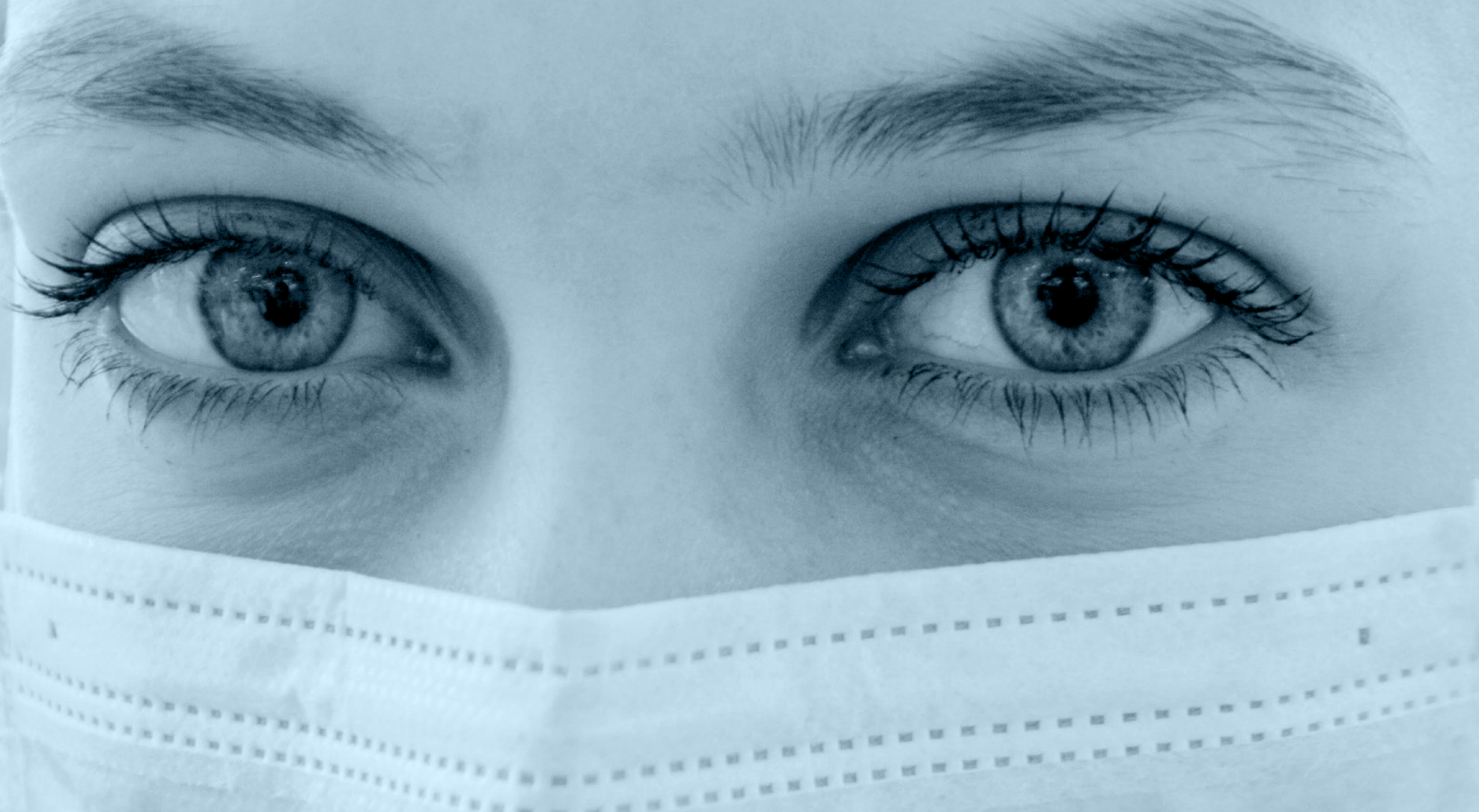

1960 til 2000 var det 111 registrerte suicid blant leger i Norge, hvorav 13 var blant kvinnelige leger (Hem et al., 2005). Fra 1960 til 1989 fant man en initial økning og så avflating av suicidratene for mannlige leger, mens det for kvinner var for lite totalt antall suicid til å kunne analysere trender (Aasland et al., 2001). I tråd med lignende endringer i befolkningen ble suicidratene blant leger noe redusert på 1990-tallet. Mannlige leger hadde da en rate på 34,3 per 100 ooo personår, sammenlignet med 24,9 for alle menn. Blant kvinnelige leger var raten $16,1 / 100$ ooo personår sammenlignet med 8,6 for kvinner generelt (Hem et al., 2005). Suicidratene i befolkningene i de nordiske land varierer både mellom land og over tid. På begynnelsen av 2000-tallet var de dobbelt så høye i Finland og Danmark som i Norge, med Sverige et sted midt imellom (Hem et al., 2000). Likevel var suicidratene blant leger i de ulike nordiske landene omtrent like høye (Hawton et al., 2011; Hem et al., 2000; Lindeman et al., 1997). Profesjonell identitet og arbeidssituasion for leger på tvers av land kan i dette henseende bety mer enn nasjonal tilhørighet (Hem et al., 2000).

I absolutte tall er det færre kvinnelige suicid enn mannlige både blant leger og i befolkningen. Men de relative suicidratene for kvinnelige leger sammenlignet med kvinner i befolkningen har vært høyere enn for mannlige leger sammenlignet med menn i befolkningen. Dette har vært diskutert å kunne ha sammenheng med at kvinnelige leger var i minoritet og at det var krevende å måtte hevde seg i et mannlig arbeidsmiljø (Hem et al., 2005). Dette kan endre seg når kvinner nå er i flertall blant yrkesaktive leger.

Blant leger i Norge var det altså i giennomsnitt i underkant av 3 registrerte suicid per år i perioden 19692000 (det kan være mørketall i forhold til registrering av suicid som dødsårsak). Det ville derfor trenges store studier og lang observasjonstid for eventuelt å kunne studere effekter av forebyggende tiltak på suicid.

Endringer i mulige risikofaktorer for suicid eller for suicidtanker/-planer blant leger kan lettere studeres. I det videre diskuteres forst noen studier som har undersøkt slike risikofaktorer for suicid blant leger. Deretter følger en presentasjon av sykdomsforebyggende tiltak for leger i Norge som ble opprettet i forlengelsen av bekymringen for legers psykiske helse, der suicid ble sett på som en ytterst mulig konsekvens. Studier som har undersøkt tiltakenes betydning for legers helse og velvære presenteres med særskilt vekt på endringer i faktorer som er identifisert som risikofaktorer for suicid. Til slutt diskuteres mulig betydning av de sykdomsforebyggende tiltakene på risikofaktorer for suicid blant norske leger, og behov for tiltak fremover.

\section{Risikofaktorer for suicid blant leger}

Det er usikkerhet knyttet til årsakene til suicid. Flere studier undersøker risikofaktorer for suicidtanker 
og suicidforsøk, men hva som fører fra suicidtanker til giennomførte suicid er usikkert. I en studie fra 1993 blant norske leger var depresjon, det å ikke leve i en parrelasjon og å være kvinne assosiert med økt risiko for suicidtanker og -planer (Hem et al., 2000). Suicidtankene ble av legene selv primært assosiert med personlige problemer (ca. 6o \%), familierelaterte problemer (ca. $45 \%$ ) og jobbrelaterte problemer (ca. $30 \%$ ). Også blant unge norske leger er depressivitet funnet å være en viktig prediktor for suicidtanker (Tyssen et al., 2004). I en senere studie fra 2010 på et representativt

\section{Utbrenthet, som følge av langvarig arbeidsrelatert stress og/eller stress i skjæringspunktet mellom jobb og hiemmet, er en form for psykisk uhelse som er blitt målt i mange studier av leger.}

utvalg av norske leger fant man at egenrapportert dårlig helse, høyt nivå av psykososialt arbeidsrelatert stress og lavt subjektivt velvære var assosiert med alvorlige suicidtanker (Rosta \& Aasland, 2013a). I denne studien fant man ikke kjønnsforskjeller.

Utbrenthet, som følge av langvarig arbeidsrelatert stress og/eller stress i skjæringspunktet mellom jobb og hjemmet, er en form for psykisk uhelse som er blitt målt i mange studier av leger. Utbrenthet, slik det vanligvis defineres med Maslachs Burnout Inventory, har ikke en direkte klinisk relevans, men emosionell utmattelse, som ofte fremholdes som hoveddimensionen av utbrenthet har delt varians med depresion (Schaufeli \& Buunk, 2003). Langtkommen utbrenthet kan resultere i depressive symptomer (Glass et al., 1993) og depressive symptomer er vist å øke risikoen for utbrenthet (West et al., 2006). Suicidtanker er funnet å være mer hyppige blant leger med høy grad av utbrenthet enn hos dem med lav grad (van der Heijden et al., 2008).

Mulige risikofaktorer for suicid er også blitt undersøkt ved såkalt psykologisk autopsimetode med interviuer og gransking av sykejournaler og andre dokumenter i etterkant av giennomforte suicid.

Blant leger som hadde tatt sitt liv i Storbritannia fant man, liksom tidligere studier har vist, høy forekomst av depresjon og medikament- eller alkoholavhengighet (Hawton et al., 2004). I en dansk studie av suicid blant leger fra 1981-2006 fant man imidlertid ingen sammenheng mellom risiko for suicid blant leger og tidligere kontakt med psykiatrisk behandling (Hawton et al., 2011). Dette kan henge sammen med manglende hielpsøking blant leger, noe man har funnet i flere studier blant leger. I en studie fra 2013 rapporterte $87 \%$ av norske leger at de gikk på jobb med «plager som de ville ha sykmeldt sine pasienter for» (Sendén et al., 2013). Finske leger som hadde tatt sitt liv hadde ofte valgt selvmedisinering for sine plager i stedet for å søke medisinsk hielp (Lindeman et al., 1998). Særlig for psykiske plager og rusproblemer er terskelen for å søke hielp høy blant leger.

Blant danske leger som hadde tatt sitt liv fant man at flesteparten hadde hatt betydelige jobbrelaterte problemer; noen hadde relasjonsproblemer og andre hadde økonomiske problemer (Hawton et al., 2011). Det var vanlig med problemer på flere arenaer samtidig. I en studie fra USA fant man oftere arbeidsrelaterte problemer blant leger som hadde tatt sitt liv enn blant andre yrkesgrupper (Gold et al., 2013).

Trusler mot opplevelse av den profesjonelle identiteten ved fysisk og psykisk sykdom eller jobbrelaterte problemer ble funnet å være en risikofaktor for suicid blant finske leger (Lindeman et al., 1998). Mange leger har en personlighet med perfeksjonistiske trekk ofte med høy forventning til egen prestasion (Tyssen, 2019). Profesjonell identitet kan oppleves truet når leger for eksempel er blitt ansvarlige for feilbehandling av pasienter eller andre uheldige pasientforløp. Den økte forekomsten av suicid blant eldre leger ( $>60$ år), til forskjell fra i øvrig befolkning, kan også ha sammenheng med tap av legeidentitet ved pensjonering eller sykdom (Hem et al., 2005).

I en litteraturgiennomgang finner Retterstøl at behandling, både med kontakt, støtte, samtaler og med adekvat medisinering, blant annet med antidepressiva, er suicidforebyggende (Retterstøl, 2015). I Norge har man ikke funnet høyere forekomst av depressive plager (Tyssen, 2019), bruk av alkohol og rusmidler (Rosta \& Aasland, 2013b), eller suicidtanker (Rosta \& Aasland, 2013a) blant leger enn blant profesjoner med sammenlignbar utdanning eller i befolkningen. Men tendensen blant leger til ikke å søke hjelp giør at det er viktig å legge til rette for at leger med denne type plager på en enkel måte kan komme i kontakt med støtte og behandling. I henhold til studier diskutert ovenfor vil det også være viktig med forebygging av uhelse ved å fokusere på arbeidssituasion og på den profesjonelle identiteten.

Tilgang til, og kunnskap om, medikamenter som suicidmetode er pekt på som en mulig årsak til at det er flere fullførte suicid blant leger enn i andre yrkesgrupper (Aasland, 2013; Hawton et al., 2011). Blant danske leger var det særlig høy andel av kvinner som brukte medikamenter som suicidmetode (75\%). Blant mannlige leger hadde halvparten brukt andre metoder, som henging og skytevåpen (Hawton et al., 2011). Også i en amerikansk studie hadde leger i stor grad brukt skytevåpen som metode (Gold et al., 2013). Det kan tyde på at lett tilgang til medikamenter ikke alene kan forklare de høyere suicidtallene blant leger. 


\section{Forebyggende tiltak for leger i Norge}

På 1980-tallet var det en diskusjon om i hvor stor grad utbrenthet og psykiske plager, okt forekomst av suicid og manglende hjelpsøking forekom blant norske leger, og hvorvidt det i så fall var profesjonsforeningens ansvar å ta vare på og behandle kolleger ved å opprette spesialiserte hielpetilbud (Isaksson Rø, 2014). Leger, som andre innbyggere i Norge, har lovfestet rett til helsehjelp. Utover dette oppfordrer de etiske reglene for leger legeprofesionen til å ta et ansvar for å «hjelpe, veilede og råde kolleger» samt «tilby hielp ved sykdom eller rusmiddelbruk». Leger skal også «ta vare på sin egen helse» (NMA, 1961, kap. 2 §2-3).

I tråd med de etiske retningslinjene, og etter innspill fra et utvalg ledet av Olaf Rutle (Rutle et al., 1988), begynte man først med en utprøving av lokale støttetiltak. Etter en evaluering i 1992 ble disse videreført og Legeforeningen opprettet fire sykdomsforebyggende tiltak relatert til legehelse på 199o-tallet. Ytterligere ett tilbud ble opprettet i 2019.

De forebyggende tiltakene skulle gi økt kunnskap om norske legers helsesituasion samt tilby lavterskeltilbud for å hjelpe leger til å oppsøke støtte og/eller behandling i tide slik at alvorlige konsekvenser for både legene og deres pasienter kunne unngås. Man ønsket å redusere risiko for alvorlig fysisk og psykisk sykdom, med suicid som en ytterst konsekvens, samt risiko for suboptimal behandling av pasienter. Beskrivelse av tiltakene og kontaktinformasion finnes lett tilgiengelig for leger på https://www.legeforeningen.no/om-oss/ helse-og-omsorgstilbud-for-alle-leger-og-medisinstudenter/. Tiltakene er i stor grad finansiert av et fond: Sykehjelps- og Pensjonsordningen for leger. Forebyggende tiltak skal begrense eller hindre en uønsket utvikling og kan deles inn i ulike nivåer (Caplan, 1964). Primærforebyggende tiltak skal forhindre at et problem oppstår i en gruppe/befolkning. Sekundærforebygging skal hindre fortsettelse eller forverring av et allerede eksisterende problem i definerte grupper eller hos individer, og tertiærforebygging skal motvirke forverring og begrense negative konsekvenser av problemer eller symptomer. For psykisk helse er grenseoppgangene mellom sekundær og tertiær forebygging flytende, og de overlapper også med behandling og strategier for å unngå tilbakefall. Tilbudene for leger dekker alle tre nivåer av forebygging.

\section{Legeforskningsinstituttet (LEFO)}

For å få kunnskap om legers helse og arbeidssituasion i Norge ble forskningsprosjektet «Legekårsundersøkelsen» initiert i 1993 (Aasland \& Falkum, 1994), og er siden fulgt opp med regelmessige spørreundersøkelser til et representativt panel av drøyt 2000 leger. Dette gir pålitelige data som viser endringer over tid i legers helse, livskvalitet og atferd og undersøker hvordan samfunnsmessige og organisatoriske betingelser påvirker muligheten for god profesjonsutøvelse, holdninger, etikk og prioritering (se www.lefo.no). Dette er en kunnskapsbase som ulike aktører (individuelle leger og legegrupper, sykehus, kommuner, Sykehjelps- og pensjonsordningen, Legeforeningen) kan bruke ved planlegging av tiltak og organisatoriske endringsprosesser i helsetjenesten, og som på den måten kan bidra til primær sykdomsforebygging.

\section{To støtteordninger for leger}

Legeforeningen opprettet to støtteordninger som skal være rådgivende og veiledende for leger og medisinstudenter som ønsker kollegial støtte. Det tilstrebes en lav terskel for kontakt ved at legen enkelt kan henvende seg på mail eller telefon uten henvisning, samtalene er helt konfidensielle og er gratis for den som søker hielp (tapt arbeidsfortjeneste kompenseres ikke). Støttetilbudene er ikke definert som behandling og det skrives ikke journal. Ordningene kan hovedsakelig forstås som sekundær- og tertiærforebyggende tiltak, selv om slike individuelle tiltak også kan ha primærforebyggende sider (Falkum, 2003).

(i) Støttekollegaordningen: «I en periode med påkjenninger - være seg privat eller profesionelt - er støttekollegenes oppgave å gi medmenneskelig støtte, råd og veiledning» (Den Norske Legeforening, 2018). Støttekolleger er erfarne leger, oppnevnte for hvert fylke av de lokale fylkesforeningene, til å bistå kolleger som trenger støtte. Det er drøyt 90 støttekolleger i Norge og de er organisert slik at de skal være geografisk lett tilgiengelige for de fleste leger. Ordningen er beskrevet som et «organisert medmenneskelig hjelpetiltak» (Isaksson Rø \& Aasland, 2016).

Støttekollegene tilbyr hver kollega som søker hjelp inntil tre samtaler; den første innen få dager etter at den hjelpesøkende har tatt kontakt. Hvert år kontaktes støttekollegaordningen av ca. 100 leger.

(i) Ressurssenteret Villa Sana: For å gi mulighet for å søke hielp uten tilknytning til sammenhengen hvor man bor og jobber, ble et sentralt støttetiltak, Ressurssenteret Villa Sana, opprettet ved Modum Bad, Vikersund. Målsettingen med tiltaket er å fremme helse og livskvalitet, styrke bevissthet og identitet i yrkesrollen samt forebygge utbrenthet ved å øke evnen til selvomsorg og hielpsøking for egen helse. Senteret tilbyr rådgivningssamtaler for individer eller par over en dag (5-6 timer) og ukeskurs for grupper av kolleger over fem dager. Det tilbys kurs både for enkeltleger og for par (Rø et al., 2007). Antall deltakere i rådgivning og kurs har økt årlig, og er nå over zoo per år.

\section{Lege-for-lege-ordning}

Ved å rekruttere og utdanne allmennpraktikere (og noen spesialister) med særlig interesse for behandling av kolleger, ønsket man å senke terskelen for leger 


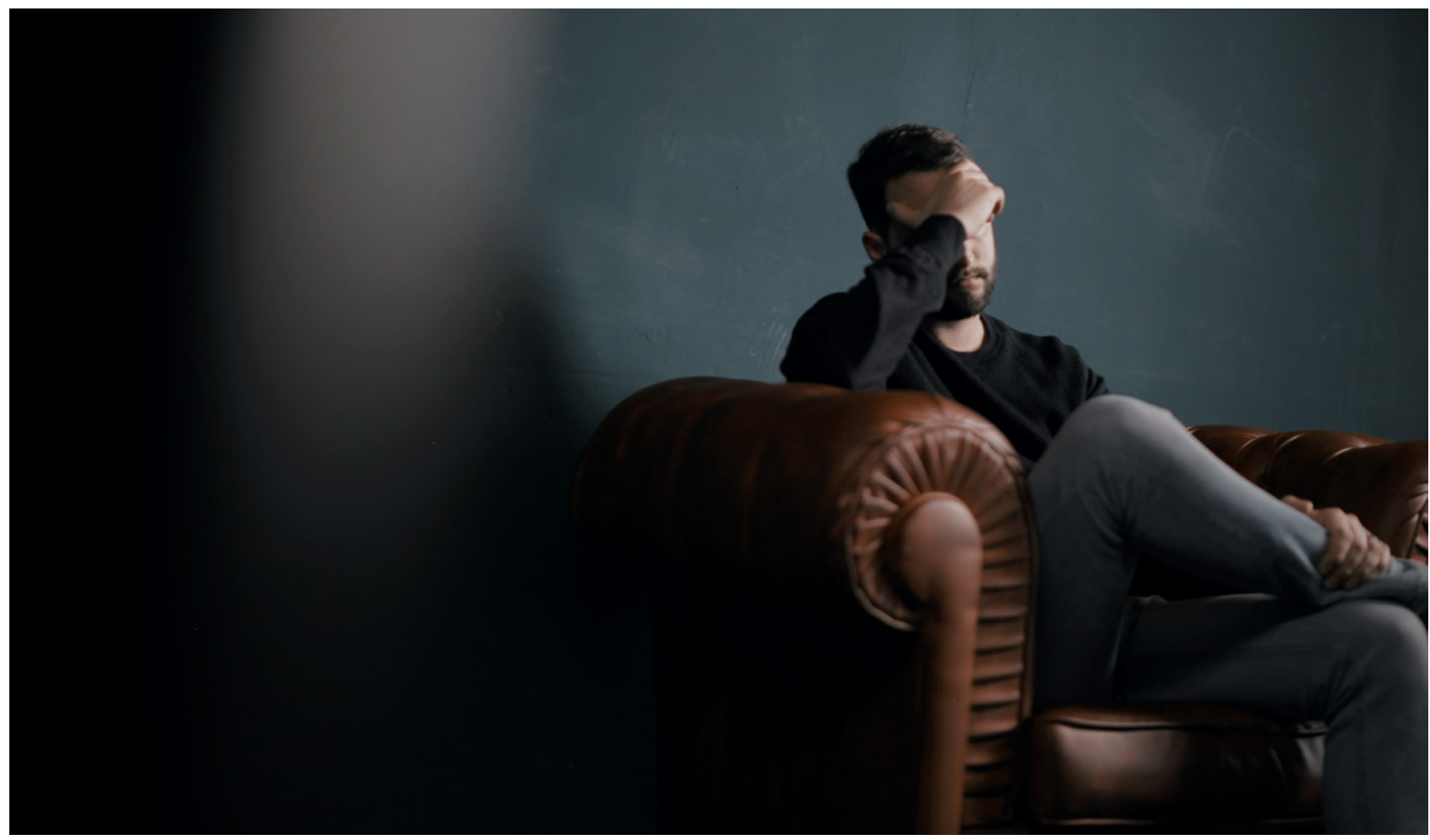

til å oppsøke behandling i den vanlige helsetjenesten. Her tilbys leger behandling der det på vanlig måte føres journal og brukes egenandel. Tiltaket kan forstås som tertiærforebyggende/behandlende. I forbindelse med innføring av fastlegeordningen gikk man bort fra ordningen i halvparten av landets fylker.

\section{Tilbud for leger med rusproblemer}

Leger med rusproblemer har i liten grad søkt seg til støtteordningene eller annen behandling og i 2019 ble det opprettet et lavterskeltilbud ved Trasoppklinikken i Oslo. Leger med rusproblemer kan henvises eller ta direkte kontakt og få tilbud om inntil fem samtaler ved denne klinikken. I løpet av de første samtalene tas det stilling til om noen støttesamtaler og råd er tilstrekkelig eller om en formell behandling skal initieres. Behandler ved Trasoppklinikken kan henvise til behandling ved egen klinikk eller et annet sted i landet.

\section{Studier av sykdomsforebyggende tilbud for leger}

Det er giort noen studier av de to norske støtteordningene for leger. Disse vil kort beskrives her, med vekt på betydning for mulige risikofaktorer for suicid. Ytterligere studier som er påbegynt nevnes.

\section{Treårs oppfølgingssstudie av leger som søkte hjelp} ved Ressurssenteret Villa Sana

I en oppfølgingsundersøkelse ble 227 (117 kvinner og 110 menn) av 242 leger (93 \%) som hadde søkt hjelp ved
Ressurssenteret Villa Sana i perioden august 2003-juli 2005 fulgt i en treårsperiode etter kontakt med senteret (Isaksson Rø et al., 2007). Ved ett- og treårsoppfølgingen var det 81 \% deltakelse (Isaksson Rø et al., 2008; Rø, 2010).

Resultatene tydet på at støttetilbudet nådde leger som var i behov av hjelp (Isaksson Rø et al., 2007). En større andel (49\%, $95 \%$ KI 43-56) av studiedeltakerne hadde høy grad av utmattelse, en dimensjon av utbrenthet, enn norske leger generelt (25\%, $95 \%$ KI 22-28). Blant de hielpsøkende legene hadde 73 \% (95\% KI 64-81) av både kvinner og menn et behandlingstrengende nivå av depressivitet og angst, sammenlignet med $14 \%$ (95\% KI 12-17) av mannlige leger og $18 \%$ (95 \% KI 14-22) av kvinnelige leger i Norge.

Studiedeltakerne rapporterte signifikant mer jobbstress enn norske leger generelt, og 21 \% (95 \% KI 15-26) av deltakerne hadde noen gang alvorlig overveid og planlagt suicid. Tilsvarende tall for norske leger generelt er $10 \%$ (95\% KI 8-12). Samtidig som resultatene tydet på at terskelen for å søke hielp ved Ressurssenteret var lavere enn for å søke hjelp i helsetjenesten, hadde likevel mange ventet lenge før de tok kontakt, og $50 \%$ av studiedeltakerne oppgav at de hadde blitt oppfordret til å søke hjelp av en kollega, partner eller andre.

Ett år etter kontakten med Villa Sana hadde deltakerne signifikant bedring i symptomer på utmattelse, arbeidsrelatert stress og depresjon og angst (Isaksson Rø et al., 2008). Flere enn halvparten av legene (53\%) hadde giennom året etter kontakten med Villa Sana 
oppsøkt samtalebehandling. Andelen sykmeldte økte i en periode etter kontakten med Ressurssenteret, men ved ettårsoppfølgingen var de aller fleste deltakerne tilbake i jobb. Reduksion i arbeidstid etter kontakten med Villa Sana predikerte bedringen i symptomer på utmattelse. Resultatene kan tyde på at både råd om behandling, sykmelding og det å motta samtalebehandling, samt vurdering av endringer i arbeidssituasion, var viktige faktorer for å oppnå bedring.

Resultatene viste at bedringen i utmattelsessymptomer og jobbstress holdt seg også ved treårsoppfølgingen av studiedeltakerne (Isaksson Rø, 2010). En reduksjon både etter ett og tre år i bruk av såkalt emosjonsfokuserte mestringsstrategier (som over tid øker risiko for slitenhet), samt bedringen i jobbstress så ut å være sterkest assosiert med bedring i symptomer på utmattelse (utbrenthet).

Lengden av heltidssykmelding etter kontakten med Villa Sana var en selvstendig prediktor for bedringen i utmattelse (utbrenthet) etter 3 år (Isaksson Rø et al., 2012). Leger er lite sykmeldt, muligens for lite siden en stor andel går på jobb med plager de ville sykmeldt sine pasienter for. Denne studien viser at sykmelding kan være viktig for å forebygge utbrenthet på sikt.

Det er viktig å minne om at dette er en naturalistisk studie uten kontrollgruppe, noe som medfører at man ikke kan vite om endringene som beskrives kan attribueres til intervensjonen og tiltak giort i etterkant av denne eller til en spontan bedring (regression toward the mean). En nylig publisert randomisert kontrollert studie fra USA viser dog lignende resultater. Etter individuell profesionell veiledning av deltakerne i intervensionsgruppen fikk leger klar bedring av utbrenthet, bedre opplevd livskvalitet og okt motstandsdyktighet etter seks måneder, mot ingen endring eller forverrelse i kontrollgruppen (Dyrbye et al., 2019).

\section{Kvalitativ studie av Støttekollegaordningen}

Fra august 2011 til juni 2012 ble 14 fokusgruppeintervjuer med totalt 61 støttekollegaer giennomført for å undersøke støttekollegaenes syn på nytteverdien av ordningen (Isaksson Rø \& Aasland, 2016).

Støttekollegene beskrev lett tilgiengelighet for hjelpsøkende leger, raskt tilbud med inntil tre samtaler, stor grad av konfidensialitet og uformell kontakt som viktige rammer for at de hielpsøkende legene oppfattet terskelen lav nok til å søke støtte.

Støttekollegene beskrev sin funksion som lyttende og støttende, og at de ved behov fremmer behandling i helsetjenesten for leger som søker hielp.

Oppsummert fremholdt støttekollegene tre avg¡ørende nytteverdier: Ordningen er holdningsskapende ved å legitimere hjelpsøking i en yrkesgruppe som har opplevd det vanskelig å søke hielp. Den er en beredskapsordning som raskt kan gi tilbud om samtale og gi trygghet om at man kan få hjelp, hvilket er forebyggende i seg selv. Ordningen er også avlastende ved å bidra til å senke den høye terskelen mange leger opplever for å søke nødvendig behandling. En støttekollega uttrykket det slik « एa, det er jo det viktigste, å få en bevissthet på at det går an å snakke med noen, det går an å få hjelp, du behøver ikke sitte alene.»

Resultatene pekte også på et mulig dilemma mellom ordningens uformelle rådgivning og støtte til den enkelte legen og et samtidig ansvar for sikkerhet, for eksempel hvis legen som søkte hjelp var akutt suicidal (Isaksson Rø et al., 2016). Disse hensynene kan noen ganger være i konflikt med hverandre.

\section{Pågående studier av helseforebyggende tiltak}

Det pågår for tiden en ny treårsoppfølgingsstudie av leger som har oppsøkt Ressurssenteret Villa Sana, der mange av de samme faktorene som i studien beskrevet ovenfor studeres.

Det pågår også en kvalitativ studie av hvorfor leger søker hjelp og hvilke endringer som giøres og oppleves etter en slik kontakt. Både leger som har oppsøkt Ressurssenteret Villa Sana, og som har oppsøkt Støttekollegaordningen interviues.

Det pågår også en studie av tilbudet for leger med rusproblemer, der man undersøker søkning til og nytteverdi av tilbudet.

\section{Diskusjon}

Internasjonalt og i Norge er det bekymring knyttet til mulige konsekvenser av legers uhelse, både for legene selv og for pasientbehandlingen (Baathe et al., 2019; Casalino \& Crosson, 2015; Panagioti et al., 2018). Høyere suicidrater blant leger enn i befolkningen for øvrig har vært en viktig motivasjon for studier av legers psykiske helse og opprettelse av sykdomsforebyggende tiltak for leger.

Det er en usikkerhet knyttet til registrering av suicid som dødsårsak og også en usikkerhet vedrørende hvilke faktorer som kan øke risikoen for suicid, som diskutert ovenfor. Den lave prevalensen av suicid giør at det å skulle måle effekt av forebyggende tiltak på suicidrater ville kreve store studier med meget lang oppfølgingstid.

Både reduksjon av suicidrater blant leger på 9o-tallet (Hem et al., 2005) og reduksjon av suicidtanker fra 2000-2010 ble observert (Rosta \& Aasland, 2013a) samtidig som ulike sykdomsforebyggende tiltak for leger i Norge ble iverksatt, men noen direkte årsakssammenheng kan ikke fastslås.

Flere studier har identifisert sannsynlige risikofaktorer for suicid blant leger, og som for andre grupper finner man okt risiko ved forekomst av depressive symptomer og av rusavhengighet (Hawton et al., 2004). I befolkningsstudier har man også relativt godt belegg for at behandling for depresion og rusavhengighet, med støtte, samtaler og medikamenter er suicidforebyggende (Retterstøl, 2015).

I Norge finner vi ikke okt forekomst av disse 
risikofaktorene blant leger (Rosta \& Aasland, 2013a; 2013b; Tyssen, 2019) sammenlignet med befolkningen for øvrig. Men derimot finner vi i mange studier, både internasjonalt og i Norge, at leger søker hjelp og får behandling i mindre grad enn andre, og som en konsekvens av dette også er sykmeldte i mindre grad enn andre grupper (Rosvold \& Bjertness, 2001; Sendén et al., 2013). Det har vært en tradisjon for at leger ikke oppsøker helsehjelp; «Lege, leg deg selv» (Bibelen, 2012, Luk, 4:23)

Dessuten har leger lett tilgang til medikamenter, og også kunnskap som giør at de i større grad oppnår sin hensikt ved suicid med medikamenter (Aasland, 2013).

Studiene av de sykdomsforebyggende tiltakene for leger i Norge tyder på at terskelen for å søke hielp giennom disse tiltakene er lavere enn i helsetjenesten for øvrig (Isaksson Rø et al., 2007). Vi ser at leger med høy grad av jobbstress og emosjonell utmattelse (utbrenthet) og leger som har depresionssymptomer og angst søker seg til støtteordningene. Resultatene fra disse undersøkelsene kan også tyde på at kontakten med støtteordningene kan motivere til å søke behandling i helsetjenesten for øvrig, til å søke psykoterapi og

\section{Situasjoner som gior at man ikke kan fungere i sin viktige pasientbehandlende rolle på grunn av fysisk eller psykisk sykdom, jobbrelaterte problemer eller alvorlige pasienthendelser, sykmelding eller pensjonering kan oppleves meget truende for legers identitet.}

til å akseptere å bli sykmeldt ved behov (Isaksson Rø \& Aasland, 2016; Isaksson Rø et al., 2008). I en akutt fase kan særlig støttekollegaordningen være viktig da den er tilgiengelig lokalt og tilbyr samtale og hielp innen meget kort tid. Dette er viktige sekundærforebyggende tiltak for den gruppen leger som kommer i kontakt med disse ordningene. Men kan tiltakene også ha en primærforebyggende rolle i hele legegruppen?

Det fremholdes at de nevnte tiltakene er holdningsskapende i profesjonen ved å legitimere hjelpsøking i en yrkesgruppe som har opplevd det vanskelig å søke hielp (Rø \& Aasland, 2016). Det at legeforeningen som profesjonsforening tar initiativ til å opprette slike tiltak for sine medlemmer kan tyde på at det skjer en gradvis endring i legeidentiteten mot en okt aksept for at leger både kan bli syke og kan trenge hielp og behandling. Legers profesjonsidentitet har vært og er fortsatt sterk. Situasjoner som giør at man ikke kan fungere i sin viktige pasientbehandlende rolle på grunn av fysisk eller psykisk sykdom, jobbrelaterte problemer eller alvorlige pasienthendelser, sykmelding eller pensjonering kan oppleves meget truende for legers identitet. Denne type situasjoner vil kunne lede til selvkritikk og depressive reaksjoner. Et holdningsskapende arbeid for å hjelpe leger til i større grad å akseptere «svakhet»og sykdom og behov for behandling på samme måte som andre mennesker, kan muligens motvirke trusler mot den grunnleggende identiteten. Hvis opprettelse av og kunnskap om de legespesifikke sykdomsforebyggende tiltakene kan bidra til en slik holdningsendring er det et viktig primærforebyggende tiltak med betydning for norske leger generelt.

Dette behovet for en holdningsendring bekreftes i sentrale dokumenter som er publisert i løpet av de seneste årene. I motsetning til at legen altruistisk skulle sette pasientens behov først, stilte det amerikanske Institute for Healthcare Improvement seg bak et såkalt "Quadruple aim of healthcare» der «Care of the patient requires care of the provider» (omsorg for pasienten krever omsorg for behandleren) fremheves som den viktige fjerde målsettingen (Bodenheimer \& Sinsky, 2014). I 2017 reviderte Verdens helseorganisasjon (WHO) den universelle legeeden, kjent som Genève-deklarasionen, der de blant annet la til et helt nytt punkt som understreker betydningen av å ivareta legers helse: «Jeg vil ivareta min egen helse, mitt velvære og mine evner, for å kunne gi omsorg av den høyeste standard.» (Parsa-Parsi, 2017).

Det er et paradoks at sykdomsforebyggende tiltak for leger i stor grad fokuserer nesten helt på individer, samtidig som forskning på årsaker til utbrenthet og arbeidsrelatert uhelse blant leger peker på organisatoriske forhold (Falkum, 2003). Mangel på opplevd mening i arbeidet, krav i form av arbeidsbelastning, manglende kontroll, manglende jobb-hjem-balanse, mangel på sosial støtte og fellesskap i arbeidssituasjonen, liten grad av overensstemmelse mellom egen og organisasjonens verdier og kultur, samt manglende tilgang til ressurser og effektiv bruk av disse er faktorer som oker risiko for stress og utbrenthet (Shanafelt \& Noseworthy, 2017). Det er mange pågående endringer i helsesektoren som har betydning for disse forholdene. Det er nye forventninger fra pasienter og fra samfunnet, med okt vekt på medbestemmelse, samvalg og brukermedvirkning. I helsetjenesten fremmes nye arbeidsmåter med mer teamarbeid innad i og på tvers av profesjoner. Dessuten bidrar okte krav om kostnadseffektivitet og ny teknologi til behov for ny forståelse av legers arbeidsoppgaver, arbeidssituasion og yrkesrolle.

Legegruppen er også i ferd med å endres i sammensetning og forventninger til arbeidsforholdene. Det er nå en overvekt av kvinner blant yrkesutøvende leger (Den Norske Legeforening, 2020) og i studentkohortene er kvinneandelen stor. Fra at de mer erfarne legene beskriver legearbeidet som «en livsstil» vil de yngre legene heller definere det som en «jobb» (Hertzberg et 
al., 2016). Blant studenter og unge leger pekes det på behov for en god jobb-hiem-balanse i arbeidssituasjonen (Fimland et al., 2019). I flere internasjonale studier rapporteres høyt jobb-hiem-stress særlig av kvinnelige leger, men i Norge fant man ikke slike kjønnsforskjeller (Hertzberg et al., 2019). I en nylig publisert studie fra Sverige oppgir både kvinnelige og mannlige medisinstudenter god jobb-hjem-balanse som et av de viktigste kriteriene i valg av fremtidig spesialitet (Diderichsen, 2017). Legers jobbtilfredshet, som i mange år har ligget stabilt, har giennom de siste årene blitt redusert både for sykehusleger og allmennpraktikere (Rosta et al., 2019). Søkningen til Ressurssenteret Villa Sana øker, særlig blant unge kvinnelige leger (Nilsen, 2017). Blant første års medisinstudenter rapporterte kvinner i 2015 høyere nivåer av depresjons- og angstsymptomer enn menn, mens det i tidligere studier ikke var kiønnsforskjeller (Ruud et al., 2020).

Dette peker på behov for organisatoriske sykdomsforebyggende tiltak på arbeidsplassen. Shanafelt og Noseworthy beskriver ulike organisasjonsendringer som er giennomført i tett samarbeid mellom leger og ledere, der leger er blitt aktivt involverte i prosesser der man har jobbet med en eller flere av faktorene som er vist å øke risiko for utbrenthet. Resultatene viser at det er mulig å oppnå økt engasjement og jobbtilfredshet (inklusive bedret jobb-hjem-balanse) blant leger, og reduksion i utbrenthetsproblemer (Shanafelt \& Noseworthy, 2017).

Også i en norsk studie pekes det på behovet for å engasjere leger i lokale organisatoriske endringsprosesser for å forebygge arbeidsrelatert stress og arbeidsrelatert uhelse (Baathe et al., 2019). Et amerikansk konsept «oy in Work» (Perlo et al., 2017) er oversatt til norske forhold. Målsettingen er å fremme legers engasjement i organisasjonsendringer for å redusere stress og øke jobbtilfredshet. Det prøves nå ut i norsk sammenheng, men er foreløpig ikke evaluert. Det er også viktig å tenke forebygging allerede i studietiden. Tiltak giennom studietiden, med informasjon og diskusion om fremtidige arbeidskår, etterlyses av studentene (Fimland et al., 2019).

\section{Konklusjon}

Høyere suicidrater blant leger enn i befolkningen for øvrig har vært en viktig drivkraft for forskning på legers helse og arbeidsforhold, og for opprettelse av sykdomsforebyggende tiltak for leger. Studier tyder på at forebyggende tiltak har betydning for å redusere risikofaktorer for suicid blant norske leger især med reduksjon av depressive symptomer og symptomer på utbrenthet og en økning i adekvat hjelpsøking. Tiltakene ser også ut å ha betydning for en holdningsendring i profesjonen, mot i større grad å tenke at det er mulig også for leger å søke hjelp ved behov. I takt med store endringer i forventninger til legerollen, både fra pasienter, samfunnet og legene selv, er det fremover viktig å iverksette både organisatoriske og individrettede forebyggende tiltak. Det bør legges til rette for et okt engasjement av leger i samhandling om organisatoriske endringsprosesser på arbeidsplassen som kan fremme arbeidsglede og motvirke utbrenthet. Også tiltak giennom studietiden er nødvendig, med informasion og diskusion om fremtidige arbeidskår, særlig ivaretakelse av god jobb-hjem-balanse.

Levert: 17.03.2020 - Revidert: 13.05.2020 - Godkjent: 04.06.2020

\section{REFERANSER}

Aasland, O. G. (1995). Legekårsundersøkelsen i Norge. Nord Med, 110, 65-67. Aasland, O. G. (2013). Physician suicide-why? General Hospital Psychiatry, $35,1-2$.

Aasland, O. G., Ekeberg, D., \& Schweder, T. (2001). Suicide rates from 1960 to 1989 in Norwegian physicians compared with other educational groups. Social Science \& Medicine, 52(2), 259-265.

Aasland, O. G., \& Falkum, E. (1994). Legekårsundersokelsen. Responsen på spørreskjemaundersøkelsen. Tidsskrift for Den Norske lægeforening, 114(26), 3052-3058.

Baathe, F., Rosta, I., Bringedal, B., \& Rø, K. I. (2019). How do doctors experience the interactions among professional fulfilment, organisational factors and quality of patient care? A qualitative study in a Norwegian hospital. BM/ Open, 9(5), E026971.

Bodenheimer, T., \& Sinsky, C. (2014). From triple to quadruple aim: Care of the patient requires care of the provider. Annals of Family Medicine, 12(6), 573-576.

Caplan, G. (1964). Principles of preventive psychiatry. London: Tavistock.

Casalino, L. P., \& Crosson, F. I. (2015). Physician Satisfaction and Physician Well-Being: Should Anyone Care? Professions and Professionalism 5(1).

Den Norske Legeforening. (1961). Etiske regler for leger. Hentet fra https:// www.legeforeningen.no/om-oss/Styrende-dokumenter/legeforeningens-lover-og-andre-organisatoriske-regler/etiske-regler-for-leger/.

Den Norske Legeforening. (2018). Støttekollegaordningen. Hentet fra https://www.legeforeningen.no/om-oss/helse-og-omsorgstilbud-for-alle-leger-og-medisinstudenter/stottekollegaordningen/.

Den Norske Legeforening. (2020). Legestatistikk. Hentet fra https://www. legeforeningen.no/om-oss/legestatistikk/\#80276.

Diderichsen, S. (2017). It's just a job: a new generation of physicians dealing with career and work ideals (Doktoravhandling, Institutionen för folkhälsa och klinisk medicin), Umeå: Umeå university.

Dyrbye, L. N., Shanafelt, T. D., Gill, P. R., Satele, D. V., \& West, C. P. (2019). Effect of a Professional Coaching Intervention on the Well-being and Distress of Physicians: A Pilot Randomized Clinical Trial. JAMA Internal Medicine, 179(10), 1406-1414.

Falkum, E. (2003). Kan utbrenthet forebygges? Tidsskrift for Den Norske Legeforening,123(13/14), 1819 .

Fimland, S. K., Kjenås, A. S., Rø, K. I., \& Schaufel, M. A. (2019). Medisinstudenters holdninger og forventninger til fremtidige arbeidsvilkår. Tidsskrift for Den Norske Legeforening, 139(17), 1660-1664.

Glass, D. C., McKnight, I. D., \& Valdimarsdottir, H. (1993). Depression, Burnout, and Perceptions of Control in Hospital Nurses. Journal of Consulting and Clinical Psychology, 61(1), 147-155.

Gold, K. I., Sen, A., \& Schwenk, T. L. (2013). Details on suicide among US physicians: data from the National Violent Death Reporting System. General Hospital Psychiatry, 35(1), 45-49. 
Hawton, K., Agerbo, E., Simkin, S., Platt, B., \& Mellanby, R. I. (2011). Risk of suicide in medical and related occupational groups: A national study based on Danish case population-based registers. Journal of Affective Disorders, 134(1), 320-326.

Hawton, K., Malmberg, A., \& Simkin, S. (2004). Suicide in doctors: A psychological autopsy study. Journal of Psychosomatic Research, 57(1), 1-4

Hem, E., Gronvold, N. T., Aasland, O. G., \& Ekeberg, Ø. (2000). The prevalence of suicidal ideation and suicidal attempts among Norwegian physicians. Results from a cross-sectional survey of a nationwide sample. European Psychiatry, 15(3), 183-189.

Hem, E., Haldorsen, T., Aasland, O. G., Tyssen, R., Vaglum, P., \& Ekeberg, ๑. (2005). Suicide rates according to education with a particular focus on physicians in Norway 1960-2000. Psychological Medicine, 35(6), 873-880.

Hertzberg, T. K., Skirbekk, H., Tyssen, R., Aasland, O. G., \& Rø, K. (2016). The good doctor - strong and persevering. Tidsskrift for Den Norske Legeforening, 136(19), 1631-1634

Hertzberg, T. K., Tyssen, R., Skirbekk, H., \& Rø, K. (2019). Work-home balance in two cohorts of Norwegian doctors. Tidsskrift for Den Norske Legeforening, 139(10).

Isaksson Ro, K. I., Gude, T., \& Aasland, O. G. (2007). Does a self-referral counselling program reach doctors in need of help? A comparison with the general Norwegian doctor workforce. BMC Public Health, 7(1), 36

Isaksson Ro, K. I., Tyssen, R., Gude, T., \& Aasland, O. (2012). Will sick leave after a counselling intervention prevent later burnout? A 3-year follow-up study of Norwegian doctors. Scandinavian Journal of Public Health, 40(3), $278-285$.

Isaksson Rø, K. I. (2010). Emotional Exhaustion and Distress after a Counselling Intervention for Physicians: A Three-year Prospective Longitudinal Cohort Study. (Doktoravhandling, Det medisinske fakultet). Universitetet i Oslo.

Isaksson Rø, K. I. (2014). Støttekollegaordningen for leger i Norge sett fra støttekollegenes side. En kvalitativ evaluering (Masteroppgave). Institutt for helse og samfunn, Det medisinske fakultet. Universitetet i Oslo.

Isaksson Rø, K. I., \& Aasland, O. (2016). Støttelegers syn på stottekollegaord ningen. Tidsskrift for Den Norske Legeforening, 136(4), 313-316.

Isaksson Rø, K. I., Gude, T., Tyssen, R., \& Aasland, O. (2008). Counselling for burnout in Norwegian doctors: One Year Cohort Study. BM): British Medical Journal, 337(7679), 1146-1149.

Isaksson Rø, K. I., Veggeland, F., \& Aasland, O. G. (2016). Peer counselling for doctors in Norway: A qualitative study of the relationship between support and surveillance. Social Science \& Medicine, 162, 193-200.

Lindeman, S., Heinänen, H., Väisänen, E., \& Lönnqvist, I. (1998). Suicide among medical doctors: Psychological autopsy data on seven cases. Archives of Suicide Research, 4(2), 135-141.

Lindeman, S., Läärä, E., Vuori, E., \& Lönnqvist, I. (1997). Suicides among physicians, engineers and teachers: The prevalence of reported depression, admissions to hospital and contributory causes of death. Acta Psychiatrica Scandinavica, 96(1), 68-71.

Nilsen, L. (2017, 05. september). Psykiater: - Virkeligheten var mye tøffere enn de hadde forestilt seg. Dagens Medisin. Hentet fra https://www. dagensmedisin.no/artikler/2017/og/o5/flere-unge-leger-sliter.

Panagioti, M., Geraghty, K., Johnson, I., Zhou, A., Panagopoulou, E., ChewGraham, C., ... Esmail, A. (2018). Association Between Physician Burnout and Patient Safety, Professionalism, and Patient Satisfaction: A Systematic Review and Meta-Analysis. JAMA Internal Medicine, 178(10), 1317-1331.

Parsa-Parsi, R. (2017). The Revised Declaration of Geneva: A Modern-day Physician's Pledge. JAMA, 318(20), 1971-1972.

Perlo, I., Balik, B., Swensen, S., Kabcenell, A., Landsman, I., \& Feeley, D. (2017). IHI Framework for Improving loy in Work. IHI White Paper Cambridge, Massachusetts: Institute for Healthcare Improvement.
Retterstøl, N. (2015). Hjelper selvmordsforebyggende tiltak? Suicidologi, 5(3).

Rosta, I., \& Aasland, O. G. (2013a). Changes in the lifetime prevalence of suicidal feelings and thoughts among Norwegian doctors from 2000 to 2010: A longitudinal study based on national samples. BMC Psychiatry, 13(1), 322.

Rosta, I., \& Aasland, O. G. (2013b). Changes in Alcohol Drinking Patterns and Their Consequences among Norwegian Doctors from 2000 to 2010: A Longitudinal Study Based on National Samples. Alcohol and Alcoholism, 48(1), 99-106

Rosta, I., Aasland, O. G., \& Nylenna, M. (2019). Changes in job satisfaction among doctors in Norway from 2010 to 2017: A study based on repeated surveys. BM/ Open, 9(9), Eo27891.

Rosvold, E., \& Biertness, E. (2001). Physicians who do not take sick leave: hazardous heroes? Scandinavian Tournal of Public Health, 29(1), 71-75.

Rutle, O., Roness, A., Ree, A., Koss, K. S., Koksvik, T., \& Haugli, L. (1988). Den oppbrukte lege. Tidsskrift for Den norske lægeforening, 108, 1819-1824.

Ruud, N., Løvseth, L. T., Isaksson Rø, K., \& Tyssen, R. (2020). Comparing mental distress and help-seeking among first year medical students over the past 20 years apart: the roles of gender and social support. BMI Open (Resubmission).

Schaufeli, W. B., \& Buunk, B. P. (2003). Burnout: An Overview of 25 Years of Research and Theorizing. In Schabracq, M. J., Winnubst, I. A. M., \& Cooper, C. L. (Eds.), The Handbook of Work and Health Psychology (Second Edition, s. 383-425). Chichester, W Sussex: John Wiley and Sons.

Sendén, M. G., Løvseth, L. T., Schenck-Gustafsson, K., \& Fridner, A. (2013). What makes physicians go to work while sick: A comparative study of sickness presenteeism in four European countries (HOUPE). Swiss Medical Weekly, 143, W13840.

Shanafelt, T. D., \& Noseworthy, I. H. (2017). Executive leadership and physician well-being: Nine organizational strategies to promote engagement and reduce burnout. Mayo Clinic Proceedings, 92(1), 129-146.

Tyssen, R. (2019). Work and mental health in doctors: A short review of Norwegian studies. Porto Biomedical Journal, 4(5), E50.

Tyssen, R., Hem, E., Vaglum, P., Grønvold, N. T., \& Ekeberg, Ø. (2004). The process of suicidal planning among medical doctors: Predictors in a longitudinal Norwegian sample. Journal of Affective Disorders, 8o(2), 191-198.

van der Heiiden, F., Dillingh, G., Bakker, A., \& Prins, I. (2008). Suicidal Thoughts Among Medical Residents with Burnout. Archives of Suicide Research, 12(4), 344-346.

Wallace, I., Lemaire, I., \& Ghali, W. (2009). Physician wellness: A missing quality indicator. The Lancet, 374(9702), 1714-1721.

West, C. P., Huschka, M. M., Novotny, P., Sloan, I., Kolars, I., Habermann, T., \& Shanafelt, T.. (2006). Association of Perceived Medical Errors With Resident Distress and Empathy: A Prospective Longitudinal Study. IAMA 296(9), 1071-1078.

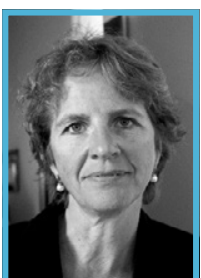

KARIN ISAKSSON RØ, PhD, MHA er leder og seniorforsker ved Legeforskningsinstituttet (LEFO). Hun er spesialist i arbeidsmedisin og har lang erfaring av forebyggende arbeid for leger som rådgiver og overlege ved Ressurssenter Villa Sana. Assosiert med Institutt for klinisk atferdsvitenskap, UiO. Foto: Kari Ronge 